\title{
Muğla'da Otopsisi Yapılan Gençlik Yaş Grubuna Ait Olguların Değerlendirilmesi
}

\author{
Evaluation of Cases Belonging to Youths Autopsied in Muğla \\ Yasemin Balcı ${ }^{1}$, Gülsüm Kadı ${ }^{1}$, Melike Erbaşs², Ümit Ünüvar Göçeoğlu ${ }^{1}$ \\ ${ }^{1}$ Muğla Sıtkı Koçman Üniversitesi Tıp Fakültesi Adli Tıp Anabilim Dalı, Muğla \\ ${ }^{2}$ Adli Tıp Kurumu, Muğla Adli Tıp Şube Müdürlüğ̈̈, Muğla
}

\section{Özet}

Amaç: Muğla'da otopsisi yapılan gençlik yaş grubu olguların değerlendirilmesiyle, gençlik grubu adli ölümlerin bölgesel profilini ç1karmak ve önlemler konusunda öneriler geliştirebilmek amaçlanmıştır.

Gereç ve Yöntem: 2013-2016 yılları arasında Muğla Adli Tıp Şube Müdürlügünde otopsisi yapılan 1603 otopsi arasında, 15-24 yaş grubunda olan $162(\% 10.1)$ olgunun otopsi raporları geriye dönük değerlendirildi.

Bulgular: En fazla otopsi 59 olguyla 2015, 39 olguyla 2016 y1llarında yapılmıştı. Olguların \%82.7'si erkek, \%17.3'ü kadındı, 15-19 yaş grubunda 76 olgu (\%46.9), 20-24 yaş grubunda 86 olgu (\%53.1) vardı. Olguların \% 75.3'ü Türkiye vatandaşı, diğerleri yabancı uyrukluydu. Olgular sırayla en fazla Bodrum, Fethiye ve Milas ilçelerinden gönderilmişti. Ölüme neden olan olaylar; 23 olguda ani beklenmedik ölüm, 50 olguda sudan çıkarılma, 19 olguda ateşli silah yaralanmas1, 45 olguda çeşitli kaza nedenli ölüm olayları idi. Ölüm nedenleri; $51(\% 31.5)$ olguda suda boğulma, $10(\% 6.2)$ olguda doğal nedenli ölüm, $90(\% 55.5)$ olguda zorlamalı ölüm olup $11(\% 6.8)$ olgunun ölüm nedeni belirlenememişti. Olguların 12'si (\%7.4) çürümüştü, bunların 10'u sudan çıkarılmıştı. Toksikolojik analizlerde 44 olguda kanda, bunların 15'inde göz içi sıvısında alkol tespit edilmişti.

Sonuç: Gençlik yaş grubu otopsi olgularında erkek oranının fazlalığı ve zorlamalı ölümlerin sıklığı dikkat çekicidir. Olguların yukarıda belirtilen ilçelerden daha fazla gelmesi durumunun, bu ilçelerde nüfusun diğer ilçelerden fazla olması bu sebeple olay sayısının da fazla olması ile ilgili olduğu düşünülmektedir. Bölgenin turizm potansiyelinin yüksek olması ve illegal göçmen geçişlerinin de bulunması beraberinde trafik, deniz kazaları ve suda boğulma olgularının sıklığını arttırmaktadır. Özellikle 20-24 yaş grubunda zorlamalı ölümlerin ve erkek cinsiyetin fazlalığı göz önüne alındığında; bu yaş grubunda erkeklerin daha fazla risk aldıkları söylenebilir. Yapılan toksikolojik analiz sonucunda 44 olguda kanda alkol saptanması da bu sonucu tetikleyen faktörlerden biri olarak düşünülmüştür.

Anahtar Kelimeler: Adli Tıp; Gençlik; Kaza; Otopsi; Travma.

Sorumlu Yazar: Doç. Dr. Ümit Ünüvar Göçeoğlu

Muğla Sıtkı Koçman Üniversitesi Tip Fakültesi Adli Tip Anabilim Dalı, Muğla

E-mail:uunuvar@gmail.com

Geliş: 12.07.2018 Düzeltme: 12.09.2018 Kabul: 18.09.2018

\begin{abstract}
Objective: The objective of this study was to evaluate the cases belonging to youths autopsied in Muğla and to reveal regional profile of deaths in forensic cases to make suggestions by evaluating these cases.
\end{abstract}

Materials and Methods: We retrospectively evaluated the autopsy reports of $162(\% 10,1)$ cases belonging to the age group of 15-24 years; out of 1603 autopsies that were done in Muğla Directorate of Forensic Medicine Institute between the years of 2013 and 2016

Results: The frequency of this age group was higher in 2015 with 59 cases and in 2016 with 39 cases. The $82,7 \%$ of cases were men and $17,3 \%$ was women, there were 76 cases $(46,9 \%)$ belonging to the age group of $15-19$ years and 86 cases $(53,1 \%)$ belonging to the age group of $20-24$ years. The $75,3 \%$ of cases were having Turkish nationality and the rest were foreigners. The cases were mostly sent from Bodrum, Fethiye and Milas accordingly. The events were reported as sudden unexpected for 23 cases, emerged from water for 50 cases, firearm for 19 cases and various accidents for 45 cases. The causes of deaths were reported for 51 cases $(31,5 \%)$ as drowning, for 10 cases $(6,2 \%)$ as natural causes, for 90 cases $(55,5 \%)$ as violent death and for 11 cases $(6,8 \%)$ as unidentified causes. There were $12(7,4 \%)$ decayed cases, 10 of these were emerged from water. In toxicological analysis alcohol was found in blood for 44 cases and for 15 of these alcohol was found also in vitreous fluid.

Conclusion: It was remarkably seen that the ratio of men and the frequency of violent deaths were higher. It was thought that the higher ratio of cases coming from the districts stated above might depend on the higher ratio of the forensic cases in these districts related with their higher population. Higher tourism potential of the region together with the presence of illegal immigration attempts may bring the higher frequency of traffic and sea accidents together with drowning. It was concluded that among the age group of 20-24 years' men show riskier behaviors when the higher frequency of violent deaths and higher ratio of men were considered. The detection of alcohol in blood for 44 cases was thought to be the one of factors triggering this result

Keywords: Forensic Medicine; Youth; Accident; Autopsy; Trauma. 


\section{Giriş}

Türkiye'nin en uzun kıyılarına sahip (1124 km) olması ve bulunduğu coğrafik konum nedeniyle Muğla, turizm açısından en gelişmiş illerden biridir. Kıyı turizmi yanı sıra, tarih boyunca birçok uygarlıklara ev sahipliği yapmış olan il kültür turizminin de önemli bir merkezi durumundadır. Özellikle yaz ve bahar aylarında yerli ve yabancı turistlerin yoğun ilgisini görmektedir. Yat turizmi kapsamında ‘tekne turlarının' büyük bölümü Muğla kıyı bandından olmaktadır. Alternatif turizm kapsamında ise; yamaç paraşütü (Fethiye- Babadağ, Milas-Ören), Kitesörf (Ula-Akyaka), rafting (Dalaman), sörf (Bodrum-Bitez, Ula-Akyaka), yelken (Bodrum, Marmaris, FethiyeKöyceğiz), tüplü dalış (Marmaris, Bodrum, Fethiye) gibi yüksek potansiyelli sporlar bulunmaktadır (1).

Türkiye İstatistik Kurumunun verilerine göre Muğla ilinin genel nüfusu; 715 binden fazladır. Bunun 376 bini erkek nüfus, 338 binini kadın nüfus oluşturmaktadır. 1519 yaş aralığında toplam 63 bin (35 bin erkek, 28 bin kadın), 20-24 yaş aralığında ise 66 bin (37 bin erkek, 29 bin kadın) nüfus olduğu bildirilmiştir (2). Muğla il ve ilçelerinde yıl içerisinde yerli ve yabancı turistlerin ilgisiyle nüfus yoğunluğu değişmektedir. Muğla iline 2013 yılında üç milyona yakın turist geldiği, ilin yılda ortalama 2 milyondan fazla turist ağırladığı bildirilmektedir (3).

Nüfusun yıl içerisinde değişkenlik gösterdiği Muğla il ve ilçelerinde adli nitelikli olayların değerlendirilmesi; Adli Tıp Kurumuna bağlı Muğla Adli Tıp Şube Müdürlügü ve Muğla Sıtkı Koçman Üniversitesi Adli Tıp Anabilim Dalı Adli Tıp Polikliniğinde yürütülmektedir. Muğla Adli Tıp Şube Müdürlüğü Morgunda yapılan otopsilere Adli Tıp Anabilim Dalı öğretim üyeleri, araştırma görevlileri ve öğrenciler de katılabilmektedir.

Bu çalışmada Muğla'da otopsisi yapılan gençlik yaş grubundaki (15-24 yaş) olguların değerlendirilmesi ile gençlik grubunda demografik özellikler yanı sıra, bölgesel özelliklerin de ortaya konmasıyla, yöresel olarak adli ölümlerin profilini çıkarmak ve önlemler konusunda öneriler geliştirebilmek amaçlanmıştır.

\section{Gereç ve Yöntem}

2013-2016 yılları arasında Adli Tıp Kurumu Muğla Adli Tıp Şube Müdürlüğünde, Muğla il ve çevre ilçelerden gönderilerek yapılan toplam 1603 otopsi olgusu içerisinden 15-24 yaş grubunda olan toplam 162 olgu çalışmaya dahil edildi. 162 genç olgunun otopsi raporları geriye dönük olarak değerlendirildi; geldiği ilçe, yaş, cinsiyet, olay türü, ölüm nedeni, orijin, toksikolojik ve histopatolojik inceleme sonuçları açısından irdelendi ve literatür ile karşılaştıııldı. Veriler SPSS programı aracılığıyla istatistiksel olarak değerlendirildi. Yüzde ve frekans değerleri ile tablo ve grafiklerle sunuldu. Olgular 15-19 ve 20-24 yaş aralığı olmak üzere iki ayrı yaş grubunda incelendi.

Çalışma, Adli Tıp Kurumu Başkanlığı Eğitim ve Bilimsel Araştırma Komisyonunun 12.12.2017 tarihli onayı ile yapild.

\section{Bulgular}

2013-2016 yıllarını kapsayan toplam 4 yıllık periyodda Muğla il merkezi ve çevre ilçelerden gönderilen toplam 1603 olguya otopsisi yapılmıştı. Bunlardan 15-24 yaş grubunda (genç) olan 162 olgu (\%10.1) çalışmaya dahil edildi. Adli otopsi uygulanan genç olguların 134'ü (\%82.7) erkek, 28'i (\%17.3) kadındı (Grafik 1).

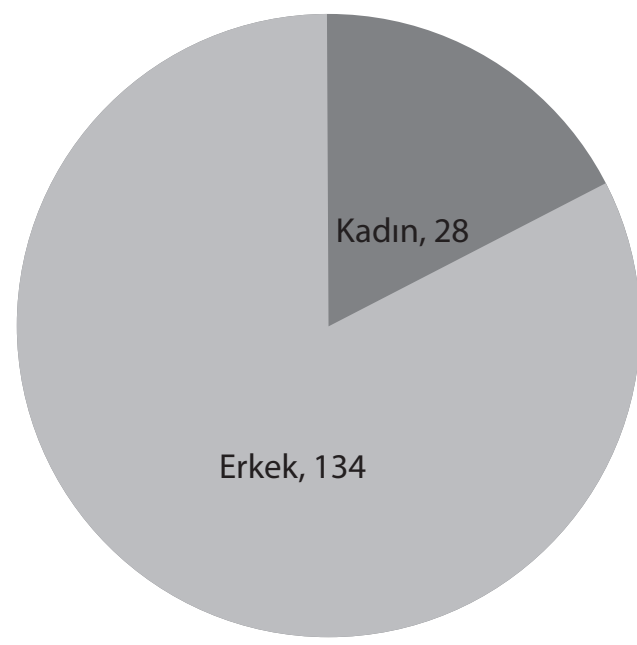

Grafik 1. Cinsiyet dağılımı (n).

Yaş gruplarına göre dağılıma bakıldığında; 15-19 yaş grubunda 76 olgu (\%46.9), 20-24 yaş grubunda 86 olgu (\%53.1) olduğu görüldü (Grafik 2).

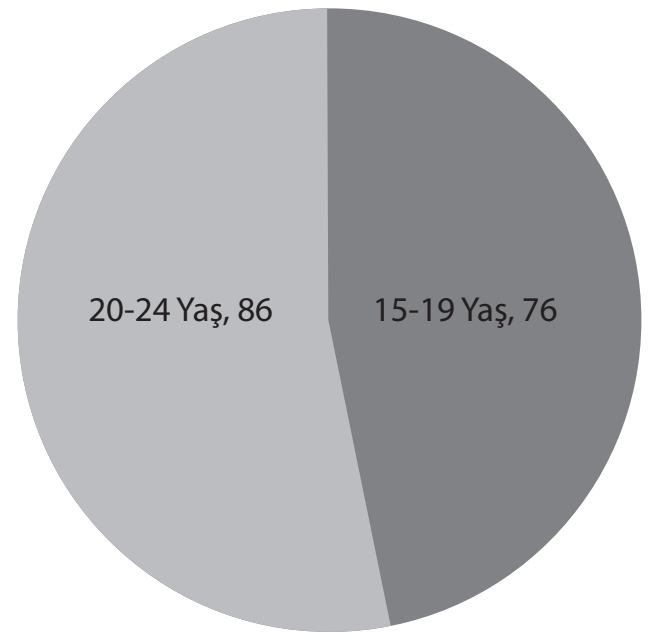

Grafik 2. Yaş gruplarına göre dağılım (n). 
En fazla otopsi 59 olgu ile 2015 yılında yapılmış bunu 39 olgu ile 2016 y1lı izlemişti (Tablo 1).

Tablo 1. Genç otopsilerinin yıllara ve yaş gruplarına göre dağılımı.

\begin{tabular}{|l|l|l|l|l|}
\hline \multirow{2}{*}{ Y11 } & \multicolumn{3}{|l|}{ Yaş grupları } & \multirow{2}{*}{ Toplam } \\
\cline { 2 - 4 } & $15-19$ & $20-24$ & Diğer yaşlar & \\
\hline 2013 & 22 & 13 & 292 & 327 \\
\hline 2014 & 14 & 15 & 320 & 349 \\
\hline 2015 & 22 & 37 & 466 & 525 \\
\hline 2016 & 18 & 21 & 363 & 402 \\
\hline Toplam & $\mathbf{7 6}$ & $\mathbf{8 6}$ & $\mathbf{1 4 4 1}$ & $\mathbf{1 6 0 3}$ \\
\hline
\end{tabular}

En fazla otopsi yapılan mevsim 56 olgu ile Sonbahar mevsimi iken, en az otopsi 29 olgu ile Kış mevsiminde yapılmışıtır (Tablo 2).

Tablo 2. Genç otopsilerinin mevsimlere göre dağılımı.

\begin{tabular}{|l|l|l|}
\hline Mevsim & $\mathrm{n}$ & \% \\
\hline İlkbahar & 36 & 22.2 \\
\hline Yaz & 41 & 25.3 \\
\hline Sonbahar & 56 & 34.6 \\
\hline Kiş & 29 & 17.9 \\
\hline Toplam & 162 & 100.0 \\
\hline
\end{tabular}

Adli otopsi uygulanan genç olguların \%75.3’ü Türkiye vatandaşı olup geri kalanları yabancı uyrukluydu. Yabanc1 uyruklu olguların 3'ü İngiltere vatandaşı, diğerleri sıklık sırasına göre Irak, Suriye, Pakistan ve Afganistan vatandaşlarıydı. Tablo 3. Olguların uyruklarına göre dağllımını vermektedir.

Tablo 3. Olguların uyruklarına göre dağılımı.

\begin{tabular}{|l|c|c|}
\hline Uyruk & $\mathbf{n}$ & $\mathbf{\%}$ \\
\hline Bilinmiyor & 2 & 1,2 \\
\hline Britanya & 3 & 1,9 \\
\hline Suriye & 11 & 6,8 \\
\hline Irak & 14 & 8,6 \\
\hline İran & 2 & 1,2 \\
\hline Pakistan & 6 & 3,7 \\
\hline Afganistan & 2 & 1,2 \\
\hline Türkiye & 122 & 75,3 \\
\hline Toplam & 162 & 100.0 \\
\hline
\end{tabular}

Adli nitelikli genç ölümleri, Muğla Adli Tıp Şube Müdürlügüne otopsi yapılmak üzere en fazla Bodrum (\%32.7), Fethiye (\%17.9) ve Milas (\%13) ilçelerinden gönderilmişti. Tablo 4. olguların otopsi yapılmak üzere gönderildikleri ilçeleri göstermektedir.

Tablo 4. Adli nitelikli genç ölümlerinin otopsi için gönderildikleri yer.

\begin{tabular}{|l|l|l|}
\hline Geldiği yer & $\mathrm{n}$ & $\%$ \\
\hline Bodrum & 53 & 32.7 \\
\hline Fethiye & 29 & 17.9 \\
\hline Milas & 21 & 13.0 \\
\hline Marmaris & 18 & 11.1 \\
\hline Merkez/Menteşe & 18 & 11.1 \\
\hline Yatağan & 7 & 4.3 \\
\hline Ortaca & 6 & 3.7 \\
\hline Köyceğiz & 6 & 3.7 \\
\hline Datça & 4 & 2.5 \\
\hline Toplam & 162 & 100.0 \\
\hline
\end{tabular}

Ölüme neden olan olayların dağılımına bakıldığında; 23 olgunun ani beklenmedik ölümler, 50 olgunun sudan çıkarılma, bir olgu kesici delici alet yaralanması, 19 olgu ateşli silah yaralanması olmak üzere toplam 20 olgu penetran travma sonucu, 45 olgunun çeşitli kaza nedenli (trafik kazası:27, iş kazası:4, elektrik çarpması:9, deniz kazası:1, zehirlenme şüphesi:1), 12 olgunun asfiktik nedenlerle ve 8 olgunun diğer travmatik nedenlerle öldüğü kayitliydı (Tablo 5).

Tablo 5. Ölüme neden olan olayların dağılımı.

\begin{tabular}{|l|l|l|}
\hline Ölüme neden olan olay & $\mathrm{n}$ & $\%$ \\
\hline Ani/beklenmedik/şüpheli ölüm & 23 & 14.2 \\
\hline Sudan çıkarılma & 50 & 30.9 \\
\hline $\begin{array}{l}\text { Penetran travmalar (KDAY*:1, } \\
\text { ASY**:19) }\end{array}$ & 20 & 12.3 \\
\hline $\begin{array}{l}\text { Kazalar (trafik kazası:27, iş kazası:4, } \\
\text { elektrik çarpması:9, deniz kazası:1, } \\
\text { zehirlenme şüphesi:4) }\end{array}$ & 45 & 27.8 \\
\hline $\begin{array}{l}\text { Diğer travmalar (künt travma:4, } \\
\text { yüksekten düşme:8) }\end{array}$ & 12 & 7.4 \\
\hline $\begin{array}{l}\text { Asfiktik ölümler (ası:11, ağız-burun } \\
\text { tıkanması:1) }\end{array}$ & 12 & 7.4 \\
\hline Toplam & 162 & 100 \\
\hline
\end{tabular}

*KDAY: Kesici Delici Alet Yarası, **ASY: Ateşli Silah Yarası

Otopsi raporlarında kayıtlı ölüm nedenlerinin dağıl1mına bakıldığında; 51 (\%31.5) olgunun suda boğulma, 10 olgunun (\%6.2) doğal nedenli (kişide mevcut hastalık sonucu), 90 olgunun (\%55.5) zorlamalı bir nedenle öldüğü tespit edilmişti, $11(\% 6.8)$ olgunun otopsi ile ölüm nedeni 
belirlenememişti. Olguların 12'si (\%7.4) çürümüştü, bunların 2'sinde şüpheli ölüm kaydı vardı, geri kalan 10'u sudan çıkarılma nedeniyle otopsiye yönlendirilmişti. Tablo 6 otopsi raporlarında kayıtlı ölüm nedenlerinin dağılımını vermektedir.

Tablo 6. Otopsi raporlarında kayıtlı ölüm nedenlerinin dağ 1 lımı.

\begin{tabular}{|l|l|l|l|}
\hline Ölüm nedeni & & $\mathrm{n}$ & $\%$ \\
\hline Suda Boğulma & & 51 & 31.5 \\
\hline $\begin{array}{l}\text { Kişide mevcut hastalık sonucu } \\
\text { (doğal nedenli) }\end{array}$ & $\mathrm{n}$ & 10 & 6.2 \\
\hline $\begin{array}{l}\text { Kalp yetmezliği, kalp-damar } \\
\text { patolojisi, myokard infarktüsü }\end{array}$ & 4 & & \\
\hline Pnömoni & 1 & & \\
\hline Subaraknoid kanama & 1 & & \\
\hline Pnömoni+ensefalit & 1 & & \\
\hline Epilepsi & 1 & & \\
\hline $\begin{array}{l}\text { Strangule ileus, peritonit, mide } \\
\text { hemorajik nekrozu }\end{array}$ & 1 & & \\
\hline Diğer & 1 & & \\
\hline Diğer zorlamalı ölümler & $\mathrm{n}$ & 90 & 55.5 \\
\hline Künt kafa travması & 11 & & \\
\hline Gıda/kusmuk aspirasyonu & 1 & & \\
\hline KDAY* & 1 & & \\
\hline ASY** & 20 & & \\
\hline Genel beden travması & 30 & & \\
\hline $\begin{array}{l}\text { İlaç, alkol, insektisit } \\
\text { intoksikasyonu, koroziv madde }\end{array}$ & 3 & & \\
\hline As1 & 11 & & \\
\hline Toksik gaz inhalasyonu & 1 & & \\
\hline Elektrik etkisi & 7 & & \\
\hline Ağız- burun tıkanması & 1 & & \\
\hline $\begin{array}{l}\text { Elle, bağla boğma+künt kafa } \\
\text { travması }\end{array}$ & 1 & & \\
\hline $\begin{array}{l}\text { Femur kırığına bağlı büyük damar } \\
\text { yaralanması }\end{array}$ & 1 & & \\
\hline Karbon monoksit zehirlenmesi & 2 & & $\mathbf{1 0 0}$ \\
\hline Belirlenemeyen & & 11 & 6.8 \\
\hline Toplam & & \\
\hline
\end{tabular}

*KDAY: Kesici Delici Alet Yarası, **ASY: Ateşli Silah Yarası

Yapılan toksikolojik analizde; 162 olgunun 44'ünde kanda 7 - $539 \mathrm{mg} / \mathrm{dl}$ arasında değişen düzeylerde alkol saptanmıştı. Kanda alkol saptanan olguların 15 'inde aynı zamanda göz içi sıvısında 9 - $333 \mathrm{mg} / \mathrm{dl}$ arasında değişen düzeylerde alkol saptanmıştı. Çürümüş olgularda $(n=12)$ kan ve göz içi sıvısı elde edilemediğinden çürüme sıvısında alkol incelenmiş olup bunların 9'unda $25-123 \mathrm{mg} / \mathrm{dl}$ arasında değişen düzeylerde alkol saptanmıştı 6 olguda kan ve idrarda, 1 olguda saçta esrar ve metabolitlerine ait etken madde, 3 olguda kanda karbonmonoksit, 33 olguda kan ya da idrarda değişik ilaç etken maddeleri bulundu.

\section{Tartışma}

Dünya Sağlık Örgütü tarafindan 15-24 yaş grubu 'genç' olarak tanımlanmaktadır (4). Türkiye İstatistik Kurumunun (TUIK) 2015 yılı verilerine göre Türkiye nüfusunun \% 16.4'ünü genç nüfus oluşturmaktadır. Bu nüfusun, $\% 51,2$ 'sini genç erkek nüfus, $\% 48,8$ 'ini ise genç kadın nüfusun oluşturduğu kayıtlıdır. Yine TUIKK verileri ölüm nedeni istatistikleri sonuçlarına göre 2015 yılında gençler arasında en fazla ölüm nedeninin dışsal yaralanma ve zehirlenmeler olduğu bildirilmiştir. Genç erkeklerde dişsal yaralanma ve zehirlenme nedeniyle ölümler $\% 57,7$ oranında gerçekleşirken, genç kadınlarda bu oranın $\% 33,8$ olduğu kayıtlıdır (5).

Çalışmamızda 4 yıllık süreçte meydana gelen adli otopsi olgularının \%10.1'ini gençlik yaş grubu oluşturmuştur. Bu yaş grubunda adli ölüm olgularının \%82.7'sinin erkek ve ölüm nedenleri arasında zorlamalı ölümlerin $\% 55.5$ oranı ile ilk sırada olduğu tespit edilmiştir. Türkiye İstatistik Kurumunun verilerine göre Muğla ilinin genel nüfusu; 715 binden fazladır. Bunun 376 bini erkek nüfus, 338 binini kadın nüfus oluşturmaktadır. 15-19 yaş aralığında toplam 63 bin (35 bin erkek, 28 bin kadın), 20-24 yaş aralığında ise 66 bin (37 bin erkek, 29 bin kadın) nüfus olduğu bildirilmiştir (2). Gençlik yaş grubu otopsilerinde erkek oranının yüksekliği, hem Muğla il ve çevresinde erkek nüfusun nispeten kadın nüfustan fazla olması ile hem de erkeklerin daha fazla adli olaylara karışıyor olması ile açıklanabilir. İzmir'de otopsi verileri üzerinden yapılan bir çalışmada genç ve orta yaş grubunda erkeklerin belirgin üstünlüğünden bahsedilmiştir (6). Katkıcı'nın (7) Sivas'ta yaptığı çalışmada; otopsi olguları içerisinde 10-19 yaş aralığının, olguların \%14.3'ünü oluşturduğu ve erkeklerin sayıca fazlalığı bildirilmiştir. Ülkemizde farklı illerde otopsi verileri üzerinden yapılan çalışmalarda, benzer şekilde gençlik yaş grubunun; olguların \%1020'sini oluşturduğu ve erkek sayısının fazlalığı bildirilmektedir (8-10). Yılmaz ve ark.nın (8) Edirne'de yaptığı çalışmada; otopsilerde kadın/erkek oranının 10/37 olduğu bildirilmiştir. Genç erkeklerin daha fazla riskli olaylara karıştığı düşünülmektedir.

Tokdemir ve ark.nın (10) Elazığ'da yaptığı çalışmada 925 olgudan oluşan 6 y1llık otopsi grubunun 204'ünün (\%22) 0-18 yaş aralığında olduğu kayıtlıdır. Karagöz ve 
ark.1 (11) bu oranı Antalya'da \% 18.3 olarak bildirmiştir. Benzer çalışmalarda oranların \%20'nin altında olduğu görülmüştür (9-13). Her ne kadar çalışmamız benzer çalışmalar gibi 0-18 yaş grubunu değil, 15-24 yaş aralığındaki gençlik yaş grubunu içerse de, oranların diğer serilerle benzer olduğu (toplam 1603 otopsi olgusunun \% 10.3'ü) düşünülmektedir.

Muğla Adli Tıp Şube Müdürlüğü Muğla il merkezinde bulunmaktadır ve otopsiler merkezdeki MORG ünitesinde, uygun ve donanımlı bir ortamda, uzman bir ekiple yapılmaktadır. Ölüm olaylarında hangi nitelikte olgulara adli otopsi yapılması gerektiği soruşturmayı yürüten Cumhuriyet Savcisı ve ölü muayenesini yapan bilirkişi hekimin inisiyatifindedir. Savcı ve muayeneye katılan hekimin deneyimine ve bilgi düzeyine göre farkl1 kararlar verilebilmektedir (13). Ceza Muhakemesi Kanunu (CMK) 87. maddesi ülkemizde otopsinin nasıl yapılacağına dair düzenlemeyi içerir. CMK madde $87^{\prime} \mathrm{e}$ göre; 'Otopsi, Cumhuriyet savclsinın huzurunda biri adlî tıp, diğeri patoloji uzmant veya diğer dallardan birisinin mensubu veya biri pratisyen iki hekim tarafindan yapılır. Müdafi veya vekil tarafindan getirilen hekim de otopside hazır bulunabilir. Zorunluluk bulunduğunda otopsi işlemi bir hekim tarafindan da yapılabilir; bu durum otopsi raporunda açıkça belirtilir.' şeklinde düzenlenmiştir. İlgili yasaya göre Cumhuriyet Savcıları adli tıp uzmanı dışında diğer hekimleri ölü muayenesi/otopsiye davet edebilmektedir. İlimizde Adli Tıp Şube Müdürlügün̈nde otopsi, adli tıp uzmanı hekimler tarafından yapılmaktadır. Ancak bazı ilçelerden özellikle kaza nedenli ölümlerde ceset otopsiye gönderilmeden adli tıp uzmanı olmayan hekimlerce de ölü muayenesi yapılarak gömme izin belgesi düzenlendiği düşünülmektedir. Dolayısıyla ilçelerden otopsi için yönlendirilen olgu sayısına bakılarak bazı ilçelerde daha az/daha fazla adli olay gerçekleşiyor şeklinde yorum yapılması doğru olmayacaktır. Benzer şekilde yapılan diğer çalışmalarda olayın daha çok il merkezinde gerçekleştiği bildirilmiştir (9-12). Bu nedenle tüm il-ilçe ve köylerde yapılan hem otopsi hem de ölü muayene raporlarını içeren çalışmaların yapılması, adli tıp uzmanı olmayan diğer uzman ve pratisyen hekimlerin ne ölçüde ölü muayenesi yaptıklarının da saptanabileceği çalışmalara ihtiyaç vardir.

Mevsimlere göre otopsi yapma oranının dağılımına bakıldığında en fazla yaz ve bahar aylarında otopsi yapıldığı, kış aylarında oranın belirgin bir şekilde azaldığ1 görülmüsştür (Tablo 2). Erzurum'da yapılan bir çalışmada otopsinin en fazla Haziran ayında (\%10.7), en az Ağustos ve Aralık aylarında yapıldığı bildirilmiştir (12). Muğla'nın turizm potansiyeli ile bahar ve yaz aylarında nüfusun artması; riskli su ve dağ sporlarının bu aylarda daha fazla yapılması; trafik yoğunluğu; alkol gibi sürüş ve spor güvenliğini etkileyecek madde kullanımının artması gibi nedenlerle otopsi oranlarının bahar ve yaz aylarında daha fazla olduğu düşünülmektedir.

Adli otopsi uygulanan genç olguların \%75.3'ü Türkiye vatandaşı olup geri kalanları yabancı uyruklu bulunmuştur. Yabancı uyruklu olguların 3'ü İngiltere vatandaş1, diğerleri sıklık sırasına göre Irak, Suriye, Pakistan ve Afganistan vatandaşlarıdır (Tablo 3).

Ölüme neden olan olaylara bakıldığında ilk sıralarda sudan çıkarılma (\%30.9) ve kazaların (\%27.8) yer aldığı görülmüştür (Tablo 5). İlimiz geçmişten beri ve özellikle de son yillarda göçmenler tarafından deniz yolunun kullanıldığı Avrupa ya geçiş yollarından biri olmuştur (14-16). Sudan çıkarılma olgularının ilk sırada olmasının bir nedeninin de bu yasadışı göçmen geçişleri olduğu düşünülmektedir. Otopsisi yapılan genç yabancı uyruklu olguların büyük çoğunluğunu Irak, Suriye, Pakistan ve Afganistan vatandaşları gibi sıklıkla Avrupa ya geçiş yapmaya çalışan ülke vatandaşlarının oluşturması, bu tür geçişlerin en sık olduğu 2015 yılına ait olgu sayılarının da diğer yıllara göre daha fazla olması (Tablo 1) ve bu tür geçişler için sıkça kullanıldığı bilinen Bodrum ilçesinden (özellikle de yakınlığı nedeniyle Bodrum ilçesinden Yunansitan Kos adasına) nispeten diğer ilçelere göre daha uzak olmasına rağmen en fazla olgunun gönderilmesi de bu düşüncemizi desteklemektedir (Tablo 4). Ayrıca bölgenin turizm potansiyelinin yüksek olması beraberinde trafik/deniz/spor kazaları ile suda boğulma olgularının sıklığını arttıran bir diğer faktör olarak düşünülmektedir.

Otopsi raporlarında kayıtlı ölüm nedenlerinin dağıl1mında (Tablo 6); benzer şekilde 51 (\%31.5) olgu suda boğulma, 90 olgunun (\%55.5) zorlamalı bir nedenle öldüğü tespit edilmiştir. Suda boğulma olgularının birisinde künt kafa travması, diğerinde patolojik beyin kanaması ve kalp yetmezliği bulguları da ölüme etkili olmuştur. Benzer çalışmalarda trafik kazaları ölüm nedenleri arasında ilk sıralarda yer almaktadır $(7-13,17,18)$. Tokdemir ve ark.nın (10) çalışmasında ilk sırada trafik kazaları, suda boğulma ve yüksekten düşmeler bildirilmiş, Katkıcı'nın (7) çalışmasında Sivas'ta ölüm nedenleri arasında ilk s1ralarda trafik kazası ve diğer kazalar olduğu bildirilmiştir. Aydın'da yapılan bir çalışmada; ölüm nedenlerinin incelenmesinde ilk sirada asfiksi (\%21.5), bunu trafik kazalar1 (\%20.1) ve patolojik ölümlerin (\%17.8) izlediği kayıtlıdır (9). Akar ve ark.nın (13) çalışmasında trafik kazaları $\% 64.5$ oranıyla açık ara ilk sırada olup bunu yüksekten düşmelerin (\%7.5) izlediği bildirilmiştir. Bizim çalışmamızda da zorlamalı nedenli ölümler arasında trafik kazalarının fazlalığı (27 olgu) dikkat çekicidir.

Ölüm nedenleri açısından cinsiyetler arasında anlamlı 
bir istatiksel fark olmasa da gençlik yaş grubunda zorlamalı ölümlerin ve erkek sıklığının fazlalığı göz önüne alındığında bu yaş grubunda erkeklerin daha fazla risk aldıkları söylenebilir. Yapılan toksikolojik analiz sonucunda 44 olguda kanda alkol saptanması da bu riskli davranışların artmasında etkenlerden biri olarak sayılabilir.

Otopsiye rağmen 11 olgunun (\%6.8) ölüm nedeni belirlenememiştir. Bu oran literatür ile uyumlu bulunmuştur $(10,13,17)$. Gençlik yaş gurubunda ölüm nedenleri arasında doğal nedenli ölüm oranları benzer çalışmalara göre daha az bulunmuştur $(9-11,13)$. Bu yaş grubunda kronik hastalık sıklığı daha az beklenmektedir.

\section{Sonuç}

Ölümlerin sayısı ve ölüm nedenlerinin gösterilmesi toplumun sağlık durumunun ortaya konması açısından önemli göstergelerden biridir. Gerek koruyucu gerekse de tedavi edici sağlık açısından ileriye dönük planlamalar için önemli bir yer tutmaktadır. Bu çalışmada 15-24 yaş gençlik yaş grubunda zorlamalı ölümlerin ve erkek sıklığının fazlalığı dikkat çekicidir ve adli ölümlerde otopsinin önemini bir kez daha ortaya koymuştur. Bu yaş grubunda erkeklerin daha fazla risk aldıkları söylenebilir. Özellikle yöremizde yaz ve bahar aylarında trafik kontrollerinin arttırılması, su/dağ sporları kontrollerinin arttırılması, gençlerin riskli davranış alabileceği konusunda ilgililerin de farkındalığının arttırılması uygun olacaktır. Türkiye genelinde durumu ortaya koyabilmek için diğer illeri de kapsayacak şekilde geniş çaplı çalışmalar yapııması yararlı olacaktır.

\section{Kaynaklar}

1. Tataroğlu M, Subaşı E. Kolluk Güçlerinde Modernleşme: Muğla Örneğinde Turizm Jandarması Yapılanması. Yönetim ve Ekonomi. 2009;16/2:73-93.

2. TUIK. Türkiye İstatistik Kurumu web sayfası. (http:// www.tuik.gov.tr/PreTablo.do?alt_id=1047 Erişim tarihi: 10.05.2018.

3. Fethiye Haber Ajans1 web sayfası. (http://www.fethiyedenhaber.com/haber/523/muglaya-gelen-turist-sayisi-3milyona-yaklasti.html Erişim tarihi: 10.05.2018.

4. Türkiye Üreme Sağlığı Programı, Cinsel Sağlık ve Üreme Sağlığı Alanında Ulusal ve Yerel Medya Yoluyla Savunuculuk Projesi, Bilgilendirme Dosyası 7: Gençlik ve Cinsellik. Editör: Selma Karabey. 2007; Cinsel Eğitim Tedavi ve Araştırma Derneği.

5. TUIK 2015 raporu; http://www.tuik.gov.tr/PreHaberBultenleri.do?id $=21517$
6. Ege B, Yemişçigil A, Aktaş EÖ, Koçak A. İzmir'de 19901994 Y1lları Arasında Otopsisi Yapılan Olguların İncelenmesi. Adli Tıp Bülteni. 1997;2(2):58-61 DOI: https://doi. org/10.17986/blm.199722225

7. Katkı1 U. Sivas'ta Adli otopsiler (1990-1995): Demografik Veriler ve Otopsiyi Yapan Hekimin Özellikleri. Adli Tip Bülteni. 1997;2(1):3-7 DOI: https://doi.org/10.17986/ blm.199721195

8. Yılmaz A, Azmak D. Trakya Üniversitesi Tip Fakültesinde Ocak 1984-Haziran 1993 Arasında Yapılmış 197 Adli Otopsinin Değerlendirilmesi. Trakya Üniversitesi Tip Fakültesi Dergisi. 1994; 11(1,2,3): 117-124.

9. Erel Ö, Katkıcı U, Pınarbaşı1ı D, Özkök S, Dirlik M. Aydın'da 2000-2003 Yılları Arasında Yapılan Adli Ölü Muayene ve Otopsilerin Değerlendirilmesi. Türkiye Klinikleri J Forensic Med. 2005; 2:44-47.

10. Tokdemir M, Kafadar H, Düzer S. Elazığ'da 2001-2007 Yılları Arasında Otopsisi Yapılan 0-18 Yaş Arası Olguların Değerlendirilmesi. Fırat Tıp Dergisi. 2009;14(2): 111-114.

11. Karagöz YM, Atılgan M, Karagöz SD, Akman R. Adli Çocuk Otopsileri. Poster Sunumu. III. Adli Bilimler Kongresi, 14-17 Nisan 1998, Aydın. Adli Tıp Bülteni. 1999; 4:120122.

12. Kır MZ, Ketenci HÇ, Başbulut AZ. Erzurum'da 2008-2009 Yılları Arasındaki Medikolegal Ölümlerin Değerlendirilmesi. Adli Tip Dergisi. 2011;25(3): 191-198.

13. Akar T, Bakar C, Şenol E, Demirel B. Gazi Üniversitesi Tıp Fakültesi Gazi Hastanesinde Adli Ölü Muayenesi Yapılan Olguların Değerlendirilmesi. Gazi Tıp Dergisi. 2005;16(4):169-171.

14. Umut Yolculuğunun Bilinmeyenleri, Yolcubaşı ve Mektep Sistemi. URL: http://appsaljazeera.com/interactive/gocmen/umut-yolculugunda-bilinmeyenleri.html Erişim tarihi: 03.03.2018.

15. Ulrich A. Illegal Immigrants in Greece. At the Mercy of the People Smugglers. Spiegel Online. URL: http://www. spiegel.de/international/europe/thousands-of-illegalimmigrants-enter-europe-through-greece-a-834415.html Erişim tarihi: 03.03.2018.

16. How do illegal immigrants get into the European Union? CNN. URL: http://edition.cnn.com/2013/10/30/world/euimmigration-infographic/ Erişim tarihi: 03.03.2018.

17. Huang C. Analysis of 3130 Cases of Medicolegal Postmortem. Fa Yi Xue Za Zhi. 1998; 14: 22-24.

18. Eyi YE, Toygar M, Karbeyaz K, et al. Evaluation of Autopsy Reports In Terms of Preventability of Traumatic Deaths. Ulusal Travma Acil Cerrahi Dergisi. 2015;21(2):127133. DOI: https://doi.org/10.5505/tjtes.2015.94658. 